Conditions of Work and Employment Branch

Wage-led or Profit-led Supply:

Wages, Productivity and Investment

\section{Servaas Storm}

C.W.M. Naastepad

Delft University of Technology, the Netherlands 
Copyright (C) International Labour Organization 2012

Publications of the International Labour Office enjoy copyright under Protocol 2 of the Universal Copyright Convention. Nevertheless, short excerpts from them may be reproduced without authorization, on condition that the source is indicated. For rights of reproduction or translation, application should be made to the Publications Bureau (Rights and Permissions), International Labour Office, CH-1211 Geneva 22, Switzerland. The International Labour Office welcomes such applications.

Libraries, institutions and other users registered in the United Kingdom with the Copyright Licensing Agency, 90 Tottenham Court Road, London W1T 4LP [Fax: (+44) (0)20 7631 5500; email: cla@cla.co.uk], in the United States with the Copyright Clearance Center, 222 Rosewood Drive, Danvers, MA 01923 [Fax: (+1) (978) 750 4470; email: info@copyright.com] or in other countries with associated Reproduction Rights Organizations, may make photocopies in accordance with the licences issued to them for this purpose.

First published 2012

ILO Cataloguing in Publication Data

Storm, Servaas; Naastepad, C. W. M.

Wage-led or profit-led supply: wages, productivity and investment/Servaas Storm, C.W.M. Naastepad; International Labour Office, Conditions of Work and Employment Branch. - Geneva: ILO, 2012

Conditions of work and employment series; No.36, ISSN 2226-8944 ; 2226-8952 (web pdf)

International Labour Office; Conditions of Work and Employment Branch

wages / labour productivity / employment / OECD countries

13.07

Cover: DTP/Design Unit, ILO

The designations employed in ILO publications, which are in conformity with United Nations practice, and the presentation of material therein do not imply the expression of any opinion whatsoever on the part of the International Labour Office concerning the legal status of any country, area or territory or of its authorities, or concerning the delimitation of its frontiers.

The responsibility for opinions expressed in signed articles, studies and other contributions rests solely with their authors, and publication does not constitute an endorsement by the International Labour Office of the opinions expressed in them.

Reference to names of firms and commercial products and processes does not imply their endorsement by the International Labour Office, and any failure to mention a particular firm, commercial product or process is not a sign of disapproval.

ILO publications can be obtained through major booksellers or ILO local offices in many countries, or direct from ILO Publications, International Labour Office, CH-1211 Geneva 22, Switzerland. Catalogues or lists of new publications are available free of charge from the above address, or by email: pubvente@ilo.org

Visit our website: www.ilo.org/publns

Printed by the International Labour Office, Geneva, Switzerland 


\section{Contents}

Preface $\quad$ V

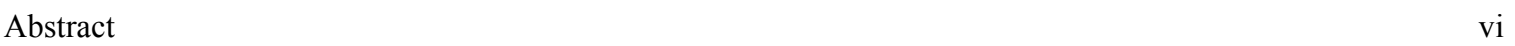

$\begin{array}{lc}\text { Acknowledgements } & \text { vii }\end{array}$

$\begin{array}{ll}\text { A Dutch Treat } & 1\end{array}$

Labour Productivity Growth 3

$\begin{array}{ll}\text { Our Model } & 5\end{array}$

What Happens to Employment Growth?

$\begin{array}{ll}\text { Evidence on OECD Employment Growth } & 15\end{array}$

$\begin{array}{ll}\text { Wages, Productivity and Profits } & 17\end{array}$

Wages and Economic Recovery 20

Conditions of Work and Employment Series $\quad 25$

\section{List of boxes, charts, figures and tables}

Figure 1 Wage-led Growth: 8

Figure 2 Profit-led Growth: $\quad 9$

Figure 3 Wage-led Growth: 13

Figure 4 A decomposition of the employment-growth impact of an increase in real wage growth (by one percentage point):

Figure 5 Profit-led Growth:

Figure 6 The employment elasticity of GDP declines when real wage growth rises.

Figure 7 The more strongly wage-led the economy, the less sensitive is profit income growth to real wage growth

Table 1 Estimates of the impact of (investment) demand growth on productivity growth

Table 2 Estimates of the impact of real wage growth on productivity growth

Table 3 Real GDP growth, hourly employment growth, labour productivity growth and real wage growth: 



\title{
Preface
}

The Conditions of Work and Employment Research Series is aimed at presenting the findings of policy-oriented research in the area of working conditions from multidisciplinary perspectives such as laws, economics, statistics, sociology and industrial relations.

Decent work concerns both the quantity and quality of employment, and indeed, the conditions of work and employment have great impacts on workers' well-being and enterprise performance. In recent years, conditions of work and employment have changed significantly in many countries, both advanced and developing, part due to globalization, technological changes, and regulatory shifts. At the same time there has been a growing recognition that improving the quality of work is also an important policy goal. Yet the challenge of what kinds of concrete policy actions need to be developed to improve the every-day reality for workers remains. With this challenge in mind, the Conditions of Work and Employment Series is intended to offer new ideas and insights on improving working conditions. It is also meant to stimulate debates among governments and social partners concerning how to better design and implement policies with the aim of ensuring decent working conditions for all workers.

ILO's Conditions of Work and Employment Branch (http://www.ilo.org/travail) is devoted to developing knowledge and policies and to providing technical assistance in the area of working conditions such as wages, working time, work organization, maternity protection and arrangements to ensure an adequate work-life balance.

\author{
Philippe Marcadent \\ Chief \\ Conditions of Work and Employment Branch \\ Labour Protection Department \\ Social Protection Sector
}




\section{Abstract}

Higher real wages provide macroeconomic benefits in terms of increased demand (if the economy is wage-led) and higher labour productivity growth and more rapid technological progress. Taking these benefits into account, we show that a wage-led (profit-led) economy becomes less strongly wage-led (profit-led). The impact of higher wages on employment growth becomes ambiguous; but for realistic model parameter values, higher real wages reduce employment growth in both wage-led and profit-led systems. Likewise, real wage restraint in a wage-led economy generates jobs - as recent Dutch experience underscores. This internal contradiction in wage-led economies can be overcome if a high wage regime is complemented by supportive fiscal and monetary policies. 


\section{Acknowledgements}

We are grateful to have received comments from Marc Lavoie, Engelbert Stockhammer, Sangheon Lee, Lance Taylor and participants of the conference "Regulating for Decent Work", International Labour Organization, Geneva, July 6-8, 2011. 



\section{A Dutch Treat}

According to standard writing class instructions, a sure-fire way to having one's manuscripts ignored is to start off with a lengthy prologue. We deliberately offend this golden rule and take a detour, treating our readers to a perhaps unusual account of a wellknown piece of recent economic history - the "Dutch employment miracle" of the 1980s and 1990s (Blanchard 2000; The Economist 2002; Becker and Schwartz 2005). What was so miraculous to many was the sharp and sustained drop in the supposedly sclerotic Dutch unemployment rate, which had peaked at more than 11 per cent of the labour force in 1982 - a rate which was 2.1 percentage points higher than the average EU-15 unemployment rate in the same year. By 1990, Dutch unemployment had come down to 5.1 per cent, a full 2.1 percentage points below the EU-15 unemployment rate in the same year, and it declined further (albeit with a temporary rise in the mid-1990s) to only 3.1 per cent in 2000, with the EU-15 unemployment rate stuck at 7.7 per cent; the Dutch managed to maintain the momentum, keeping unemployment down at 3.8 per cent of the labour force during the period 2000-2010, a full 4 percentage points lower than the unemployment rate in the EU-15. This "labour market success", as Peter Auer (2000) called it, is generally ascribed to the Dutch socio-economic model, colloquially known as the "Polder Model".

The label "Polder Model" is apt, not only because the Netherlands features some 3,000 man-made polders (with the oldest ones dating back to the $11^{\text {th }}$ century), but also because polder construction has always involved much employment including public relief works in the depression years of the 1930s. "God created the world, but the Dutch created Holland" - with a lot of labour input. In fact, the recent Polder Model has no rival when it comes to employment creation. During the 1960s and 1970s, economic growth in the Netherlands, as in the wider EU-15 area, failed to generate positive growth in employment (measured in hours worked). For the Netherlands this changed drastically after 1982: during the 1980s and 1990s, one percentage point of real GDP growth generated about 0.6 percentage points of employment growth (measured in hours). The change for the EU-15, in contrast, was small: post-1982, one percentage point of real GDP growth in the EU-15 is associated with only about 0.1 percentage point of employment growth. Agnostic observers have tried to argue that the superior employment performance of the Netherlands is a statistical artifact, based on fiddling with the unemployment data and/or definitions or due to a shortening of average work hours as a result of the significant increase in part-time work. Both claims are wrong. The Dutch labour participation rate has been rising steadily after the mid-1980s and is among the highest in the OECD area. And the average work week in the Netherlands is not much shorter than that of other EU countries. So what is the secret of Dutch job creation?

As the by now rather cliché story goes, the foundations of the economic rénaissance of the Netherlands were laid in 1982, when employers, unions and the government signed the Wassenaar Agreement, under which the unions promised to deliver pay restraint in exchange for a new emphasis on jobs. Ever since, real wage growth in the Netherlands has been kept below productivity growth and - so the story goes - this allowed firms' profits to go up, led to new investments and thus created new jobs. It must be said that voluntary wage restraint was not done half-heartedly ${ }^{1}$ : annual nominal wage growth (per hour), amounting to more than 11 per cent in the 1970s, was brought down to about 2 per cent during 1984-2000; real wage growth (per hour worked) was cut from 4 per cent per

${ }^{1}$ All data in this section are from Naastepad (2006). 
year in the 1970s to about zero in the later period. Dutch wage moderation has been exceptional in an international context: on average, annual Dutch real wage growth was 0.5 percentage points below average OECD real wage growth in the 1980s and 1990s. As a result and as intended, the Dutch wage share (in GDP at factor cost), which stood at about 65 per cent at the end of the 1970s and in the early 1980s, was brought down to 56 per cent during 1984-2000, and the profit share, correspondingly, increased from 35 per cent to slightly more than 44 per cent. It is true that investment (as a proportion of GDP) increased following the recovery in profitability, but the increase was only modest and by far not large enough to give a boost to Dutch economic growth.

It is here were most observers actually go wrong in their analysis of the Jobs Miracle: Dutch real GDP growth post-1982 has been inferior to Dutch growth performance in the 1960s and 1970s, even though there was a restoration of profitability to pre-profit squeeze levels. That growth did not respond to the heavy dose of wage moderation should not have come as a surprise, however: the Dutch economy, after all, is wage-led (Naastepad 2006; Naastepad and Storm 2007; Tavani, Flaschel and Taylor 2011). Hence, real wage restraint and the consequent fall in the wage share led to a net contraction of aggregate demand which depressed, not raised, economic growth. With demand out of wage incomes falling, the Dutch could only sustain - modest - growth after 1982 by means of increased reliance on growing world demand (for Dutch exports) and a growing dependence on (household) debts and (housing) wealth gains as a source of consumption demand. The Dutch central bank has estimated that about half of Dutch GDP growth during 1995-2005 has been due to loan-financed and wealth-gain funded consumption growth. Without these rather dubious sources of growth, the shine of the Dutch employment miracle would have worn off already more than 10 years ago.

It is also important to our discussion that Dutch growth performance after 1982 has not been significantly superior to that of the EU-15: between 1984 and 1996, annual Dutch real GDP growth was only slightly higher than that of the EU-15 (2.8 per cent versus 2.7 per cent, respectively). This means that the far better employment growth of the Netherlands (vis-à-vis the EU-15) cannot in any way be attributed to superior growth performance. What remains is just one explanation: the source of the Dutch employment miracle has been inferior labour productivity growth. This is brought out by the data. Annual Dutch labour productivity growth (measured per hour of work) was roughly equal to average productivity growth in the EU-15 in the 1970s. But during 1984-2000, average Dutch labour productivity growth was about 0.6 percentage points lower than EU-15 productivity growth, and it is this gap in productivity growth which is the cause of relatively rapid Dutch employment growth and its lower unemployment rate (Naastepad 2006; Storm and Naastepad 2011). The flip side of low productivity growth has been a substantial increase in the Dutch low-wage employment share, made possible by a policy of labour market deregulation - from less than 10 per cent of total persons employed in the early 1980s to about 18 per cent in the early 2000s (Salverda 2009).

It is not well understood, and this is rather unfortunate, that the slowdown of Dutch labour productivity growth itself is almost completely due to the widely praised policy of real wage restraint. The reason is (as we will argue in the main part of the paper in more detail) that lower real wage growth slows down labour productivity growth in two major ways:

- by depressing the growth of aggregate demand, real wage growth restraint reduces productivity growth through the so-called Kaldor-Verdoorn effect; and

- directly, by retarding the rate of labour-saving technological progress, because lower wage growth reduces firms' incentives to invest in labour-saving R\&D. 
About 90 per cent of the Dutch productivity growth slowdown after 1982 must be attributed to the policy-engineered decline in real wage growth (Naastepad 2006). And the sharp productivity growth decline, in turn, fully explains the remarkable improvement in Dutch employment growth post-1982. The Dutch Employment Miracle, in other words, is better called a "Productivity Crisis" - and we don't see much ground for urging the rest of Europe to learn from it and adopt a similar model.

This darker side of the miracle is not widely recognized in the Netherlands itself. For example, in line with the consensus view, Dutch unions, in clear defiance of standard insider-outsider models, were happy to give priority to creating jobs for the unemployed over obtaining higher wages for the already-employed by means of real wage restraint. Political support for wage moderation has been truly across the board with only the fringe-left being a party pooper. The Dutch social democratic party (PvdA) has supported real wage moderation from the outset, while in opposition, and also later, when wage moderation and labour market deregulation became key parts of its own Third Way economic strategy, thought appropriate to a new post-industrial capitalism. Tellingly, the motto of the two consecutive governments (1994-2002) under the leadership of social democratic Prime Minister Wim Kok was "jobs, jobs, jobs"-a motto Mr. Kok also gave to the report of the Employment Taskforce, which he chaired in 2003 on behalf of the European heads of state. What the durable Mr. Kok, who is not a man of many words, actually meant is that full employment, mostly based on low-wage flexible services jobs, should take precedence over inequality as a goal of economic policy-in one blow discarding European social democratic thought in favour of narrow Anglo-Saxon NAIRU logic (Judt 2010). In Third Way opinion, it ought to be left to markets to dictate investment and jobs, while government should be used in a traditional liberal manner to make workers more competitive and protect them (within limits) from illness, disability and poverty. Damning the Netherlands with faint praise, we conclude that a major lesson from the Dutch experience is that a policy of real wage restraint can be very successful in a wage-led economy - provided, of course, the prime goal is the creation of low-wage flexible (service-sector) jobs in an economy growing mostly due to debt-financed demand.

At this point our guided tour to the Low Countries has come to an end. It is fair to ask: what are its general lessons or broader insights for growth and employment, if any? Cutting out the details, two key lessons emerge. First, in the macro scheme of things, labour productivity growth is an endogenous variable, far too important to be ignored, which is influenced by (wage-led or profit-led) demand and real wage growth. Below we investigate how productivity growth interacts with demand and employment growth in a simple (but realistic) demand-led growth model. Second, as the Dutch example illustrates, real wage restraint may generate strong employment growth, even if the economy is wage-led. It follows that one has to be cautious claiming that higher wages in a wage-led economy will generate "jobs, jobs, jobs" (because aggregate demand expands) as long as it is unclear how strongly the wage hike is affecting labour productivity growth. The Dutch example should stand out as an unforgiving warning signal-cautioning against unwarranted optimism that there is no trade-off between higher wages and lower unemployment in wage-led economies. Capitalism's internal contradictions cannot be wished away.

\section{Labour Productivity Growth}

The crucial general point is that labour productivity growth is endogenous: it depends - in a structural sense - on aggregate demand growth and real wage growth. The careful reader of this sentence may wonder what we mean by the phrasal adjective "in a structural sense". The point here is that in a regime in which trend ("structural") real 
wage growth is high, for instance, a sudden temporary drop (or rise) in real wage growth will not (significantly) affect productivity growth - because this does not affect firms' R\&D investments. However, a more permanent (and credible) change-from a regime with rapid real wage growth to one with low or zero wage growth, as in the Netherlands after 1982 - will affect $R \& D$, investment, capital intensity of production and hence productivity growth. Our analysis of the macroeconomic effects of real wage changes thus concerns (policy) regime change - and is therefore medium-term in nature.

A simple linear formulation of endogenous labour productivity growth is:

$$
\hat{\lambda}=\beta_{0}+\beta_{1} \hat{x}+\beta_{2} \hat{w}+\ldots . . \quad \beta_{0,} \beta_{2}>0 ; \quad 0<\beta_{1}<1 .
$$

where $\hat{\lambda}$ is labour productivity growth (lettering a circumflex over a variable denotes its growth rate), $\hat{x}$ is real GDP growth, and $\hat{w}$ is real wage growth. We claim that coefficients $\beta_{1}$ and $\beta_{2}$ are positive and statistically significantly so. Evidence on the coefficients is provided in Tables 1 and 2 .

Coefficient $\beta_{1}>0$ is the Kaldor-Verdoorn effect: it is the increase in productivity growth caused by growth in aggregate demand and output. Aggregate demand growth leads to an economy-wide deepening of the division of labour as well as more rapid learning-by-doing (in firms), which are processes which eventually get reflected in higher labour productivity growth. Moreover, to the extent that demand growth is investment growth, the new investments result in higher labour productivity, because the newly installed equipment embodies the latest state of production technologies and is therefore more productive than older vintages of capital stock. The most comprehensive study on the Kaldor-Verdoorn effect - which captures the impact of demand on productivity growth - is McCombie, Pugno and Soro (2002), who review 80 empirical studies and conclude that the overwhelming majority of these studies - irrespective of the differences in econometric methods and data employed - find a causal link from demand growth to productivity growth. Table 1 lists ten more recent studies, which confirm McCombie et al.'s conclusion. The (simple) average value of $\beta_{1}$ for the group of OECD countries is 0.46 ; estimates for individual countries are quite close to the OECD average. Let us therefore assume, as stylised fact, that $\beta_{1}=0.46$.

Coefficient $\beta_{2}>0$ reflects the positive impact of higher real wage growth on labour productivity growth. The explanation of this effect goes back at least to Karl Marx, who argued in Capital that high wages lead to a labour-saving bias in innovation and technological progress - because only labour-saving technological progress, which he identifies with rising labour productivity, ensures the reproduction of a positive economic surplus. Higher wages thus stimulate capital deepening, drive inefficient firms off the market and encourage structural change, increase the proportion of high-skilled workers in the labour force, and, in general, promote labour-saving technological progress. Marx's idea of wage-cost induced technological progress has gone through various incarnations, including Hicks (1932), Kennedy (1964) and more recently Foley and Michl (1999) and Funk (2002). ${ }^{2}$ Table 2 summarizes recent findings on the impact of real wage growth on labour productivity growth - our coefficient $\beta_{2}$. The statistical evidence assumes that

\footnotetext{
2 It also has an important contemporary analogy in the view of climate economists that "steady pressure from $[\ldots]$ a high carbon price $[. .$.$] would [. .$.$] unleash the decentralized power of capitalist [. .$.$] inventive genius$ on the problem of researching, developing, and finally investing in economically efficient carbon-avoiding alternative technologies" (Weitzman 2007, p. 723).
} 
causality runs from wage growth to productivity growth, which appears reasonable in view of the fact that wage growth mostly follows from an institutionalized process of bargaining (as in NAIRU theory for instance) and therefore "leads" movements in aggregate labour productivity, as autonomous real wage pressures drive profit-seeking firms to increase labour productivity by means of labour-saving technological progress. ${ }^{3}$ Long-run evidence for 19 OECD (1960-2004) provided by Vergeer and Kleinknecht (2010-11) shows that $\beta_{2}$ varies between 0.31 and 0.39 . Our own findings for 20 OECD countries during 1984-2004 indicate that $\beta_{2}$ is about 0.3 (Storm and Naastepad 2009, 2011). Estimates of $\beta_{2}$ for individual economies including France, Germany, the Netherlands, the UK, the USA and the Scandinavian countries are consistent with the (simple) average value of 0.38 for the group of OECD countries. We assume, as a second stylised fact, that $\beta_{2}=0.38$ - an increase in real wage growth by 1 percentage point is associated with an increase in labour productivity growth by 0.38 percentage points. Both stylized facts play a crucial role in our theoretical analysis.

\section{Our Model}

To investigate how productivity growth interacts with output and employment growth, we use a three-equation growth model:

$$
\begin{aligned}
& \text { (1) } \hat{\lambda}=\beta_{0}+\beta_{1} \hat{x}+\beta_{2} \hat{w}+\ldots . . \quad \beta_{0} \beta_{2}>0 ; 0<\beta_{1}<1 . \\
& \text { (2) } \hat{x}=\Theta+C[\hat{w}-\hat{\lambda}] \\
& \text { (3) } \hat{\ell}=\hat{x}-\hat{\lambda}
\end{aligned}
$$

Where employment growth (i.e. labour demand growth) equals $\hat{\ell}$. Equation (1) is the productivity growth equation. Real wage growth is a distributional variable, which is determined as the outcome of institutionalized negotiation and bargaining between unions and employers' associations. In equation (2), demand growth is expressed as a function of real wage growth and productivity growth, and autonomous demand growth $\Theta$. $C$ is the all-important slope coefficient. If $C>0$, an increase in real wage growth raises output growth and hence the economy is wage-led. The reason is that faster real wage growth (at a given rate of productivity growth) redistributes income from (higher-saving) profits to (lower-saving) wages, raising the wage share, in other words. This raises consumption growth and the increase in consumption growth is larger (in absolute terms) than the decline in investment and export growth (induced by lower profits and higher unit labour costs). Output growth consequently expands. Conversely, if $C<0$, an increase in real wage growth depresses output growth, hence the economy is profit-led. All this is fairly standard as is equation (3) which is an identity: employment growth is the difference between output growth and productivity growth by definition. Using (1), we can express $\hat{\ell}$ as a function of only output growth:

$$
\text { (4) } \hat{\ell}=\left(1-\beta_{1}\right) \hat{x}-\beta_{0}-\beta_{2} \hat{w}
$$

\footnotetext{
${ }^{3}$ Marquetti (2004), using data for the US economy over the 130-year period 1869-1999, finds unidirectional Granger causality from the real wage to labour productivity.
} 
Combining equations (1), (2) and (4), we solve for the equilibrium rates of output and labour productivity growth $\hat{x}, \hat{\lambda}$ and equilibrium employment growth $\hat{\ell}$ :

$$
\begin{aligned}
& \text { (5) } \hat{x}=\frac{\Theta-\beta_{0} C}{1+\beta_{1} C}+\frac{\left(1-\beta_{2}\right) C}{1+\beta_{1} C} \hat{w}=\bar{\Theta}+\Xi \hat{w} \\
& \text { (6) } \hat{\lambda}=\beta_{0}+\beta_{1} \bar{\Theta}+\left[\beta_{2}+\beta_{1} \Xi\right] \hat{w} \\
& \text { (7) } \hat{\ell}=-\beta_{0}+\left(1-\beta_{1}\right) \bar{\Theta}+\left[\left(1-\beta_{1}\right) \Xi-\beta_{2}\right] \hat{w}
\end{aligned}
$$

where $\quad \bar{\Theta}=\frac{\Theta-\beta_{0} C}{1+\beta_{1} C} ; \Xi=\frac{\left(1-\beta_{2}\right) C}{1+\beta_{1} C}$; and $\Phi=\frac{\beta_{3} C}{1+\beta_{1} C}$. These equilibrium expressions can be used to analyze how output, productivity and employment growth are affected by a strategy of real wage restraint, operationalized as a reduction of real wage growth $(\Delta \hat{w}<0)$. What are the effects of lower real wage growth?

From (5), it follows that:

$$
\text { (8) } \frac{d \hat{x}}{d \hat{w}}=\frac{\left(1-\beta_{2}\right) C}{1+\beta_{1} C}=\Xi
$$

What does equation (8) mean? To facilitate the discussion, first assume that labour productivity growth is exogenous: $\beta_{1}=\beta_{2}=0$, hence $\hat{\lambda}=\beta_{0}$. Expression (8) then simplifies into $(d \hat{x} / d \hat{w})=C$, which is positive (negative) if demand is wage-led (profit-led). This is the standard case of demand-led growth which assumes given productivity growth.

Consider now the general case in which $\beta_{1}$ and $\beta_{2}$ are positive. We note that $\frac{1}{1+\beta_{1} C}$ represents an "endogenous-technology" multiplier which captures the process of cumulative causation implied by the Kaldor-Verdoorn relationship (if the KaldorVerdoorn coefficient $\beta_{1}=0$, the endogenous-technology multiplier vanishes). It follows from the model's stability conditions that the denominator $1+\beta_{1} C$ of (8) is positive (Naastepad 2006). Accordingly, the sign of $(d \hat{x} / d \hat{w})$ depends on whether the numerator $\left(1-\beta_{2}\right) C$ is positive or negative. We know-as a stylized fact-that $0<\beta_{2}=0.38<1$, hence the sign of $(d \hat{x} / d \hat{w})$ in the general case continues to depend on the sign of $C$-as in the standard case. That is, if $C>0$, growth is wage-led; and if $C<0$, growth is profit-led. Endogenous productivity growth therefore does not change the overall (wage-led or profit-led) nature of the system-for values of the "wage-cost induced technological progress effect" $\beta_{2}<1$.

However, even though there is no qualitative change, taking the Kaldor-Verdoorn and induced innovation effects into account does mean that (8) changes in a quantitative sense. Let us first consider the wage-led case $C>0$ and assume that $C=0.30$ (which is realistic for the EU and individual EU-countries, see Stockhammer et al. 2009; Naastepad and Storm 2007; Onaran and Galanis 2012), and using $\beta_{1}=0.46$ and $\beta_{2}=0.38$, we get: 


$$
\frac{d \hat{x}}{d \hat{w}}=\frac{(1-0.38) C}{1+0.46 C}=\frac{0.62 \times 0.30}{1+0.46 \times 0.30}=0.16
$$

The total impact of a one-percentage-point decline in real wage growth on (wageled) output growth is -0.16 per cent-points - which is roughly half of the direct impact given by coefficient $C{ }^{4}$ What ( $\left.8^{\prime}\right)$ indicates is that the total damage to GDP growth of real wage restraint is rather limited even if the economy is (moderately) wage-led. For example, even an unprecedented cut in real wage growth by a full 4 percentage points, as experienced by Dutch workers post 1982, would reduce annual output growth by about 0.64 percentage point — not by 1.2 percentage points as one would have expected looking only at the direct impact given by $C=0.30$. The reason is simple: if wage growth declines, and if as a result, labour productivity growth also declines, then unit labour cost growth $\hat{w}-\hat{\lambda}$ declines less than real wage growth itself-and hence output growth declines less (equation 2). In Figure 1, we plot the values of the direct impact (coefficient $C$ ) against the corresponding values of the total impact (coefficient $\Xi$ ) for the wage-led case-assuming that $\beta_{1}=0.46$ and $\beta_{2}=0.38$. The total impact is about half the size of the direct impact - endogenous productivity growth makes the economy, in other words, considerably less strongly wage-led. To drive home this point, note that if $\beta_{2} \rightarrow 1$, $(d \hat{x} / d \hat{w}) \rightarrow 0$, i.e. the impact on output growth of reduced real wage growth becomes smaller (in absolute terms) and eventually vanishes, the more $\beta_{2}$ approaches a value of one. This is illustrated in Figure 1 by the lower curve which represents coefficient $\Xi$ calculated assuming that $\beta_{2}=0.70$. This leads us to an important qualification: a higher sensitivity of labour productivity growth to real wage growth reduces the strength of the wage-led nature of aggregate demand. This impact of a decline in wage growth on productivity growth is generally ignored in models of demand-led growth and hence the impact of a change in wage growth on demand growth $(d \hat{x} / d \hat{w})$ is overestimated, the more so, the higher is the value of $\beta_{2}$.

\footnotetext{
${ }^{4}$ Note that Onaran and Galanis (2012) actually find a much lower value for $C$ for the EU: 0.08 . From equation (8'), we then get: $\frac{d \hat{x}}{d \hat{w}}=\frac{(1-0.38) C}{1+0.46 C}=\frac{0.62 \times 0.08}{1+0.46 \times 0.08}=0.05$. A 1 per cent-point reduction in real wage growth in this case leads to only a 0.05 per cent-point decline in real GDP growth.
} 


\section{Figure 1 Wage-led Growth:}

The direct versus the total impact of a one-percentage point increase in real wage growth

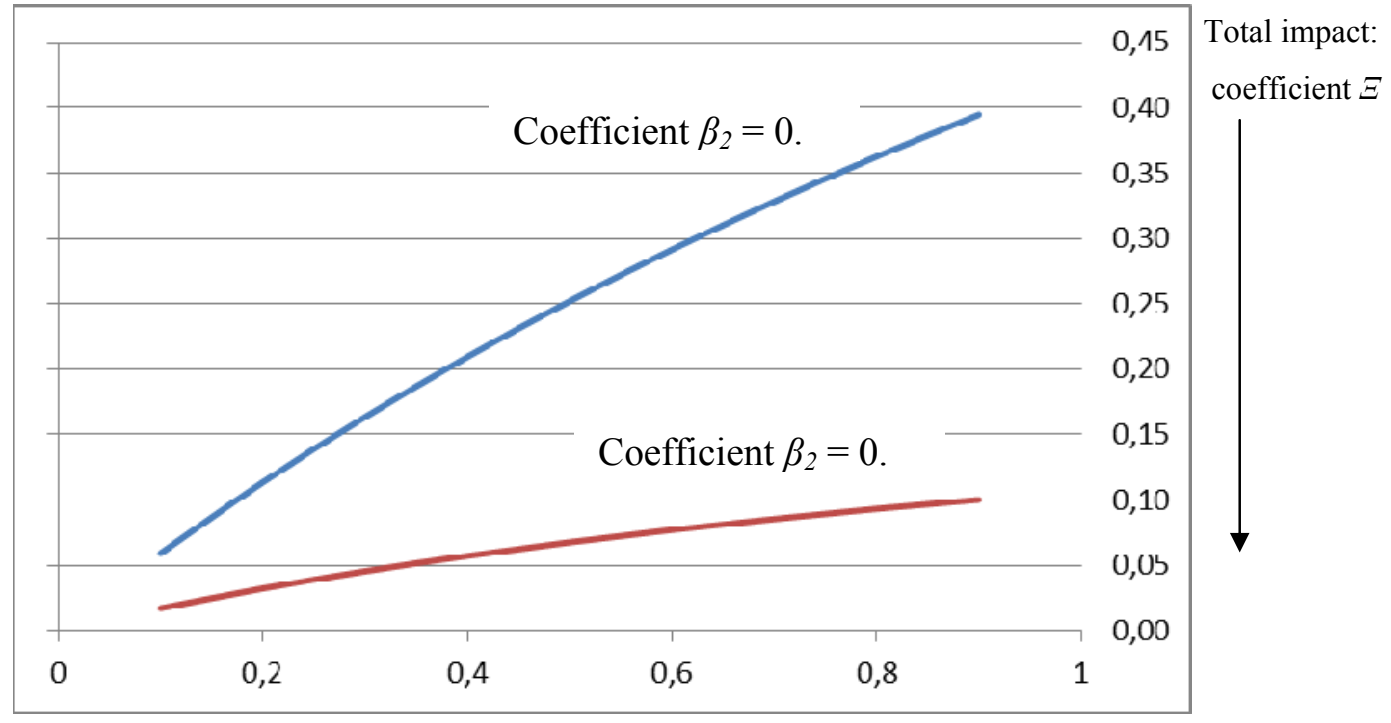

Direct impact on demand growth

of a 1 per cent-point rise in real wage

Note: The upper line represents the total impact on output growth of a 1 per cent-point increase in real wage growth when we assume that coefficient $\beta_{2}=0.38$; the lower line (in red) gives the total impact on output growth of a 1 per cent-point increase in real wage growth when $\beta_{2}=0.70$.

Consider now the profit-led case $C<0$ and assume that $C=-0.23$ (which, we think, is realistic for the USA; see Naastepad and Storm 2007) ${ }^{5}$, we obtain:

$$
\text { (8”) } \frac{d \hat{x}}{d \hat{w}}=\frac{(1-0.38) C}{1+0.46 C}=\frac{0.62 \times(-0.23)}{1+0.46 \times(-0.23)}=-0.16
$$

The total impact of a one-percentage-point decline in real wage growth on (profitled) output growth is +0.16 per cent-points. This is the net result of the following three changes:

- the one-percentage point decline in real wage growth (with unchanged productivity) raises the profit share and increases output growth, in standard exhilarationist fashion, by 0.23 per cent-points - coefficient $C$.

- faster output growth, in turn, raises labour productivity growth (through the Kaldor-Verdoorn effect) and this raises the profit share further, adding another

\footnotetext{
${ }^{5}$ We must note here that the empirical evidence on the nature of the US demand regime is mixed. On the one hand, Bowles and Boyer (1995), Barbosa-Filho and Taylor (2006), Tavani, Flaschel and Taylor (2011), Storm and Naastepad (2012) and Nikiforos and Foley (2012) find that US demand is profit-led (as we assume here). On the other hand, Hein and Vogel (2008), Onaran, Stockhammer and Grafl (2011) and Onaran and Galanis (2012) conclude that US demand is wage-led. While the issue is empirically unresolved, we provide a theoretical case why profit-led demand is consistent with the US stock-market based financial system (Storm and Naastepad 2012, Chapter 5).
} 
0.03 per cent-points of output growth. The combined increase in the rate of output growth thus is 0.26 per cent-points. However,

- the decline in real wage growth at the same time depresses productivity growth via coefficient $\beta_{2}$. Lower productivity growth reduces the profit share and lowers output growth by 0.1 per cent-points. Taken together, we arrive at the total impact of +0.16 per cent-points.

The bottom line is that even though the productivity-growth effects of real wage restraint do not change the profit-led nature of the system, they do make the system somewhat less strongly profit-led. This can be seen from Figure 2, where we plot the values of the direct impact (coefficient $C$ ) against the corresponding values of the total impact (coefficient $\Xi$ ) for the profit-led case-again assuming that $\beta_{1}=0.46$ and $\beta_{2}=0.38$. The total impact is somewhat smaller than the direct impact-endogenous productivity growth makes the economy, in other words, less strongly profit-led. Note (again) that if $\beta_{2} \rightarrow 1,(d \hat{x} / d \hat{w}) \rightarrow 0$, i.e. the growth promoting impact of lower real wage growth becomes smaller, the more $\beta_{2}$ approaches unity.

\section{Figure 2 Profit-led Growth:}

The direct versus the total impact of a one-percentage point increase in real wage growth

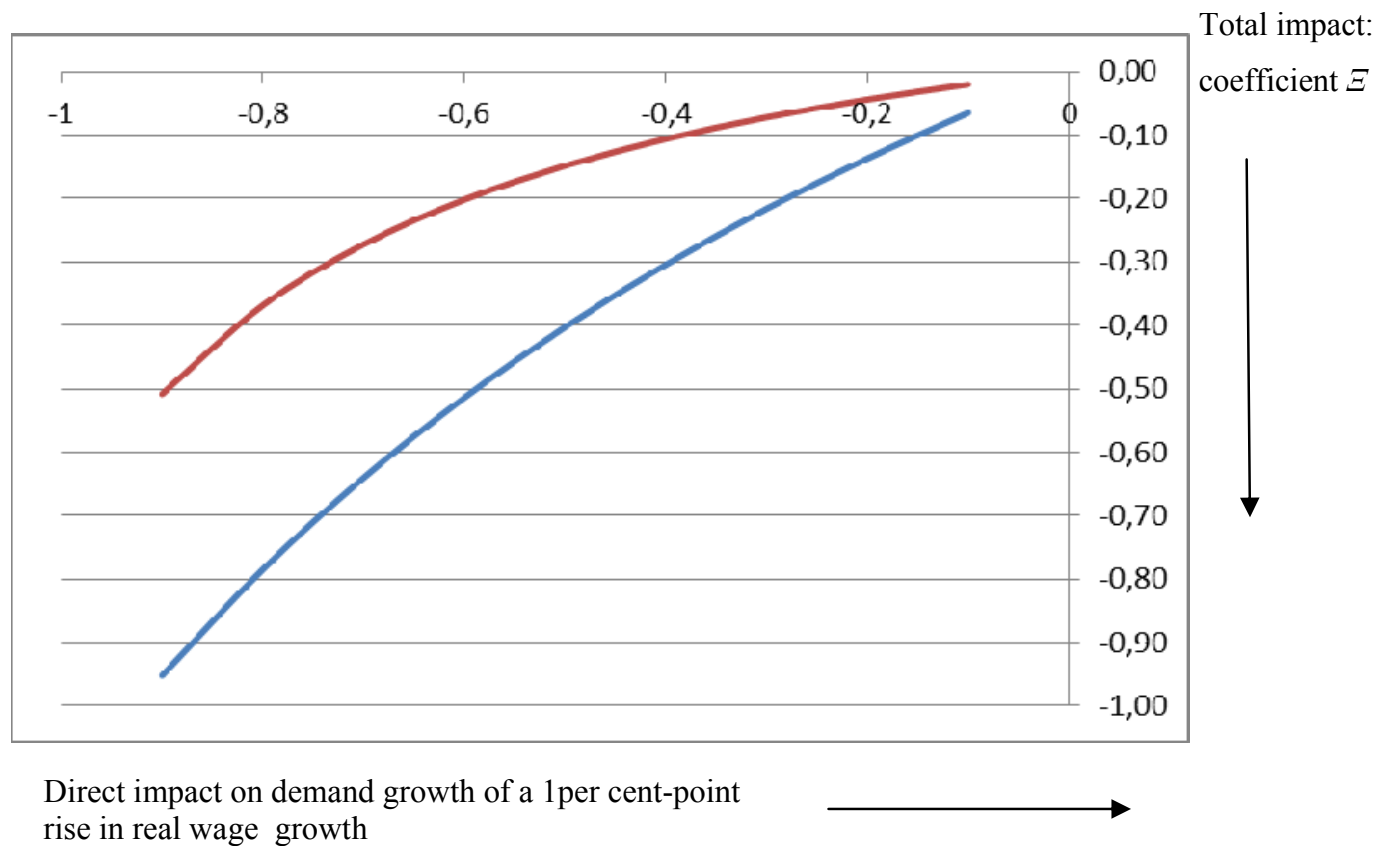

Note: The upper line represents the total impact on output growth of a 1 per cent-point increase in real wage growth when we assume that coefficient $\beta_{2}=0.38$; the lower line (in red) gives the total impact on output growth of a 1 per cent-point increase in real wage growth when $\beta_{2}=0.70$.

What can we say about the total impact of reduced real wage growth on equilibrium productivity growth when demand is wage-led? From (1), and using (8), it follows that

$$
\frac{d \hat{\lambda}}{d \hat{w}}=\beta_{2}+\beta_{1} \frac{d \hat{x}}{d \hat{w}}=\beta_{2}+\frac{\beta_{1}\left(1-\beta_{2}\right) C}{1+\beta_{1} C}=\frac{\beta_{2}+\beta_{1} C}{1+\beta_{1} C}
$$


A reduction in real wage growth has direct and indirect effects on productivity growth. The direct effect is a decline in productivity growth by $\beta_{2} \Delta \hat{w}$; (permanently) lower wage growth reduces the incentive for firms to invest in labour-saving technological progress. The indirect effect is equal to the change in long-run demand growth, caused by the decrease in real wage growth $(d \hat{x} / d \hat{w})$ multiplied by the KaldorVerdoorn elasticity $\beta_{1}$. If the economy is wage-led, $(d \hat{\lambda} / d \hat{w})$ is always positive, because $C>0$. Reduced real wage growth therefore always depresses long-run productivity growth - directly (providing less inducement to improve technology) and indirectly (by reducing demand, which reduces productivity growth via the KaldorVerdoorn channel). Let us again put in some numbers for the wage-led case:

$$
\frac{d \hat{\lambda}}{d \hat{w}}=\beta_{2}+\beta_{1} \frac{d \hat{x}}{d \hat{w}}=0.38+0.46 \frac{d \hat{x}}{d \hat{w}}=0.38+0.46 \times 0.16=0.46
$$

For realistic parameter values, we find that a reduction in real wage growth by one percentage point depresses labour productivity growth by about 0.5 percentage points. Obviously, the retardiation of productivity growth becomes stronger, the larger are the coefficients $\beta_{1}$ and $\beta_{2}$. What should also be clear is that real wage growth restraint reduces productivity growth more than output growth - thus creating higher employment, a fact that has been cunningly exploited by the Dutch Polder builders to much international acclaim. The upshot of our theoretical discussion of a wage-led economy is that subdued wage growth leads to subdued output growth while hampering labour productivity growth at the same time. The outcome, in that case, may well be increased employment growth (and lower unemployment), but this is achieved by depressing productivity growth (rather than raising profitability, investment and export and output growth). Lower unemployment, in other words, compromises welfare and the overall technological dynamism of the wage-led system. We come back to employment in a separate section below.

What happens to productivity growth in the profit-led case? Going back to equation (9), we note that - given that now $C<0$ - the numerator can be positive, zero, or negative depending on the size of the coefficients. If $0 \leq \beta_{2}<-\beta_{1} C$, the numerator is negative and a decline in real wage growth raises productivity growth, because the wage-cost induced productivity growth decline is more than offset by the increase in productivity growth due to higher (profit-led) demand growth (the Kaldor-Verdoorn effect). This would be a case in which real wage growth restraint raises both output and productivity growth. But if $\beta_{2}>-\beta_{1} C$, then $(d \hat{\lambda} / d \hat{w})$ is positive and lower wage growth leads to reduced productivity growth (even though output growth increases). Again, putting in some numbers, this time for the profit-led case, may help:

$$
\text { (9”) } \frac{d \hat{\lambda}}{d \hat{w}}=\beta_{2}+\beta_{1} \frac{d \hat{x}}{d \hat{w}}=0.38+0.46 \frac{d \hat{x}}{d \hat{w}}=0.38+0.46 \times(-0.16)=0.31
$$

Given our parameter values and assuming that $C=-0.23$ (the profit-led US-case), a reduction in real wage growth by one percentage point depresses labour productivity growth by about 0.3 percentage points, which is a smaller decline than in the wage-led case of (9'). The main reason, of course, lies in the Kaldor-Verdoorn effect, which is positive in the profit-led case because output expands in response to lower wage growth 
(whereas it is negative in the wage-led case). Productivity growth in a profit-led economy slows down more strongly in response to real wage restraint, the larger is coefficient $\beta_{2}$; however, it will be affected less strongly, the larger is coefficient $\beta_{1}$. Employment growth increases in response to the reduction in wage growth, this much we can already conclude, because profit-led output growth rises while productivity growth falls. But let us zoom in more closely on the employment impacts of real wage restraint in wage-led and profit-led economies.

\section{What Happens to Employment Growth?}

From (8) and (9), we derive the following employment growth effect of reduced real wage growth:

$$
\frac{d \hat{\ell}}{d \hat{w}}=\frac{d \hat{x}}{d \hat{w}}-\frac{d \hat{\lambda}}{d \hat{w}}=\left(1-\beta_{1}\right) \frac{d \hat{x}}{d \hat{w}}-\beta_{2}=\frac{\left(1-\beta_{1}-\beta_{2}\right) C-\beta_{2}}{1+\beta_{1} C}
$$

Let us consider the case of a wage-led economy (i.e. $C>0$ ). The total impact on employment growth is the net result of three separate (and opposing) effects of reduced real wage growth:

(i) employment growth declines due to a decrease in output growth because demand is wage-led $(d \hat{x} / d \hat{w})>0$;

(ii) employment growth increases due to the direct decline in labour productivity growth via $\beta_{2}$; and

(iii) employment growth increases because labour productivity growth falls via the Kaldor-Verdoorn coefficient $\beta_{1}$.

The sign of $d \hat{\ell} / d \hat{w}$ depends on the magnitude of each of these effects and, hence, employment growth may rise or fall in response to the fall in real wage growth. Formally, if $C>\frac{\beta_{2}}{1-\beta_{1}-\beta_{2}}$ then $d \hat{\ell} / d \hat{w}>0$, because the decline in employment induced by lower wage growth is larger (in absolute terms) than the rise in employment caused by slower productivity growth (also the result of lower real wage growth). Under wage-led demand $(C>0)$, this condition is always met if we assume that $\beta_{2}=0$; hence, absent wage-cost induced technological progress, lower real wage growth results in lower employment growth - in clear violation of what Keynes called the second postulate of classical employment theory. The picture changes and becomes more neoclassical, however, when $\beta_{2}>0$; for high values of $\beta_{1}$ and especially $\beta_{2}$, the sign of $d \hat{\ell} / d \hat{w}$ becomes negative: in other words, a decline in real wage growth may then lead to a rise in employment growth, mainly because of its negative impact on induced labour-saving technological progress and productivity growth and the consequent positive effect on the growth of demand.

If we apply our stylized facts to equation (10), and assume that $C=0.30$ (as for the EU), we get: 


$$
\left(10^{\prime}\right) \frac{d \hat{\ell}}{d \hat{w}}=\frac{d \hat{x}}{d \hat{w}}-\frac{d \hat{\lambda}}{d \hat{w}}=\left(1-\beta_{1}\right) \frac{d \hat{x}}{d \hat{w}}-\beta_{2}=(1-0.46) \times 0.16-0.38=-0.29
$$

A one-percentage point decline in real wage growth raises employment growth by about 0.3 percentage points in this prototype wage-led economy. For the Dutch case of a 4 percentage-point fall in real wage growth, this suggests an increase in employment growth of 1.2 percentage points. ${ }^{6}$

Figure 3 shows how the employment growth rate will be affected by a onepercentage point decline in real wage growth, when the economy becomes more strongly wage-led, i.e. $C$ increases from 0.3 up to 0.9 . It can be seen that the employmentgenerating effect of real wage restraint is smaller, the more strongly wage-led the economy is. However, perhaps surprisingly, even in very strongly wage-led economies (where $C>0.80$, as in the Scandinavian countries; see Storm and Naastepad 2012), lower wage growth creates more employment - the reason is that, also in these economies, productivity growth is more sensitive to real wage growth than aggregate demand growth. Hence, co-operative wage-led capitalism faces one inescapable problem: lack of employment growth. Higher real wage growth likely leads to bigger increases in productivity than in output growth, which implies that employment growth declines. While this deeper problem may lose importance in the near future (due to the ageing of Europe's labour force), a more pro-active approach is to cut annual working hours (as in the 1960s) and/or to expand, often essential, public-sector (tax-financed) employment in health, education and environmental protection ("green jobs")-what Adolph Lowe $(1988,100)$ aptly called "planned domestic colonization", the creation of public-sector jobs to strengthen (public) infrastructure and provide essential services in health, education and general welfare. Lowe's proposal, which ties in with the basic income scheme proposed by Andrew Glyn (2006), Richard Sennett (2005) and many others, advocates "a type of investment that will enlist millions of job-seeking workers, whom the private domain cannot employ, in productive activity".

\footnotetext{
${ }^{6}$ In our model, higher real wage growth leads to a fall in employment growth. However, technological progress may have an independent impact on accumulation and growth which our model does not take into account (see Lavoie 1992, pp. 316-326), because "waves of innovations" can shift the investment function up. This effect can be captured by restating equation (2) as follows: $\hat{x}=\Theta+C[\hat{w}-\hat{\lambda}]+D \hat{\lambda}=\Theta+C \hat{w}-[C-D] \hat{\lambda}$, where coefficient $D$ reflects the direct impact of innovation growth. The claim is that if $D$ is sufficiently large, faster productivity growth will raise output growth and hence an increase in real wages in a wage-led demand regime may have a neutral effect on employment, meaning that $\frac{d \hat{\ell}}{d \hat{w}}=0$. Using our parameter estimates and assuming $C=0.30, D$ would have to equal 0.87 to have a neutral employment growth impact of higher wage growth; if $C=0.10$ (as for the EU in Onaran and Galanis (2012)), $D$ would take a value of 1 . While the effect may exist - especially following the introduction of new general-purpose technologies - we think it is unlikely to be of empirical importance for the OECD countries (1960-2010). The main reason we believe so, is that if $D=0.87$, empirically demand would turn out to be very strongly wage-led - the total impact of wage share growth on demand growth would have to equal 0.7 , which is much higher than what most econometric studies find (again, see Onaran and Galanis (2012)).
} 


\section{Figure 3 Wage-led Growth:}

The impact on employment growth of a one-percentage point decrease in real wage growth for weakly and strongly wage-led economies

Total increase in the employment growth rate when productivity growth is endogenous

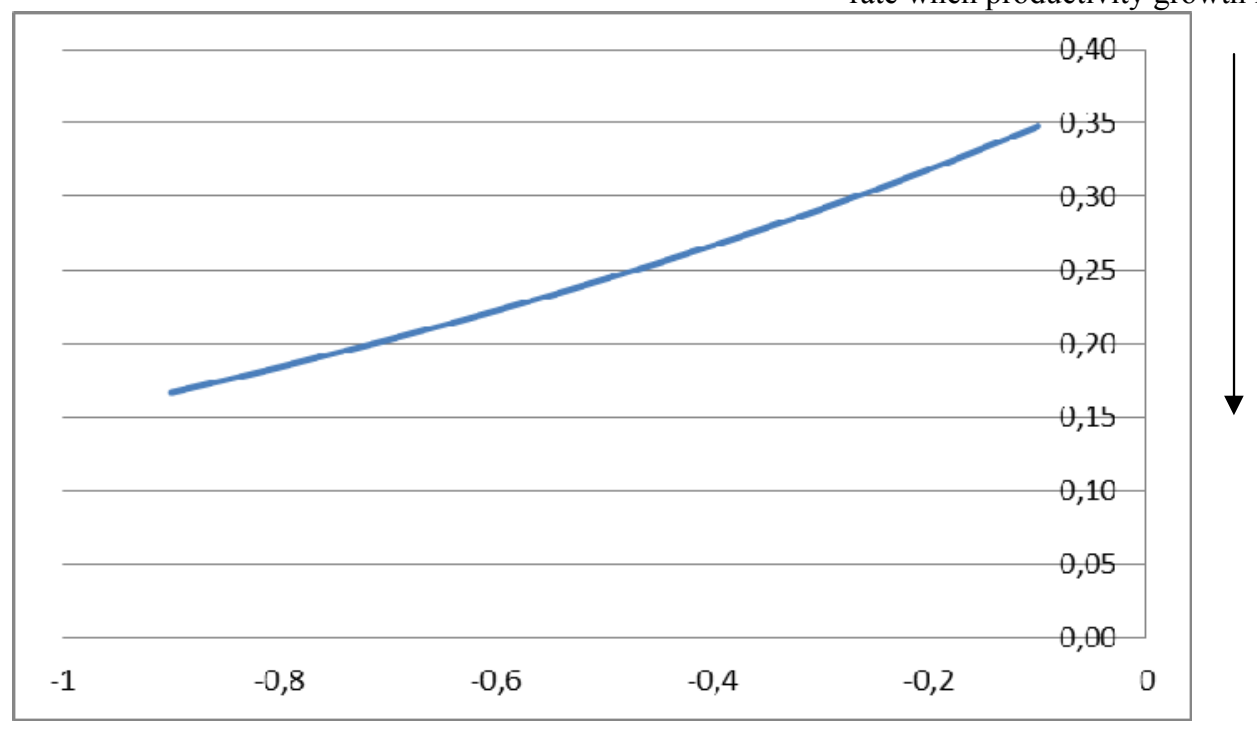

Decline in employment growth when productivity is exogenous (coefficient $\mathrm{C}$ )

In Figure 4, we decompose the total impact on employment growth of a onepercentage point decline in real wage growth. The immediate impact, assuming that productivity growth does not respond, is a 0.3 percentage point decline in employment growth - this is what exogenous-technology models of wage-led growth would predict. But productivity growth slows down and hence the wage share declines less than the real wage; consequently, output growth and labour demand growth fall less - by only 0.16 per cent-points. Accordingly, employment growth declines by 0.16 per cent-points. The decline in labour productivity growth in addition raises labour demand-by 0.46 per centpoints. Therefore, the total impact on employment growth equals +0.29 per cent-points. The contrast is striking: in the exogenous-productivity model, lower wage growth reduces employment growth by 0.3 per cent-points; but in the endogenous-productivity model, it raises employment growth by 0.3 per cent-points. "Ignorance never settles a question", British Prime Minister Benjamin Disraeli famously remarked far back in 1866-clearly, endogenous changes in productivity growth are far too important to be ignored.

Employment growth in a profit-led system increases due to lower real wage growth, because $C<0<\frac{\beta_{2}}{1-\beta_{1}-\beta_{2}}$. For our parameter values, we find that

$$
\text { (10”) } \frac{d \hat{\ell}}{d \hat{w}}=\frac{d \hat{x}}{d \hat{w}}-\frac{d \hat{\lambda}}{d \hat{w}}=\left(1-\beta_{1}\right) \frac{d \hat{x}}{d \hat{w}}-\beta_{2}=(1-0.46) \times(-0.16)-0.38=-0.47
$$


This means that real wage restraint in profit-led systems is pretty effective in raising employment growth and reducing unemployment.

Figure 4. A decomposition of the employment-growth impact of an increase in real wage growth (by one percentage point):

The wage-led case

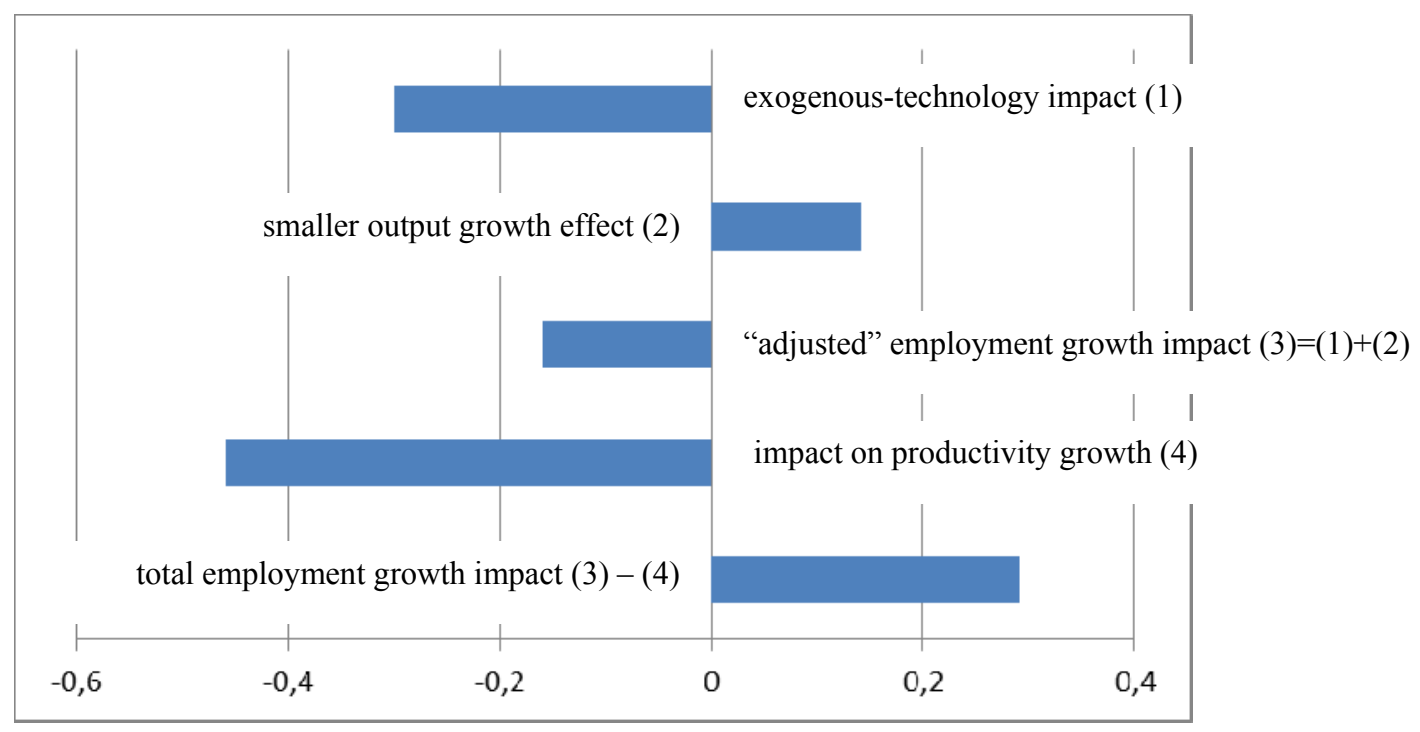




\section{Figure 5 Profit-led Growth:}

The impact on employment growth of a one-percentage point decrease in real wage growth for weakly and strongly profit-led economies

Increase in the employment growth rate

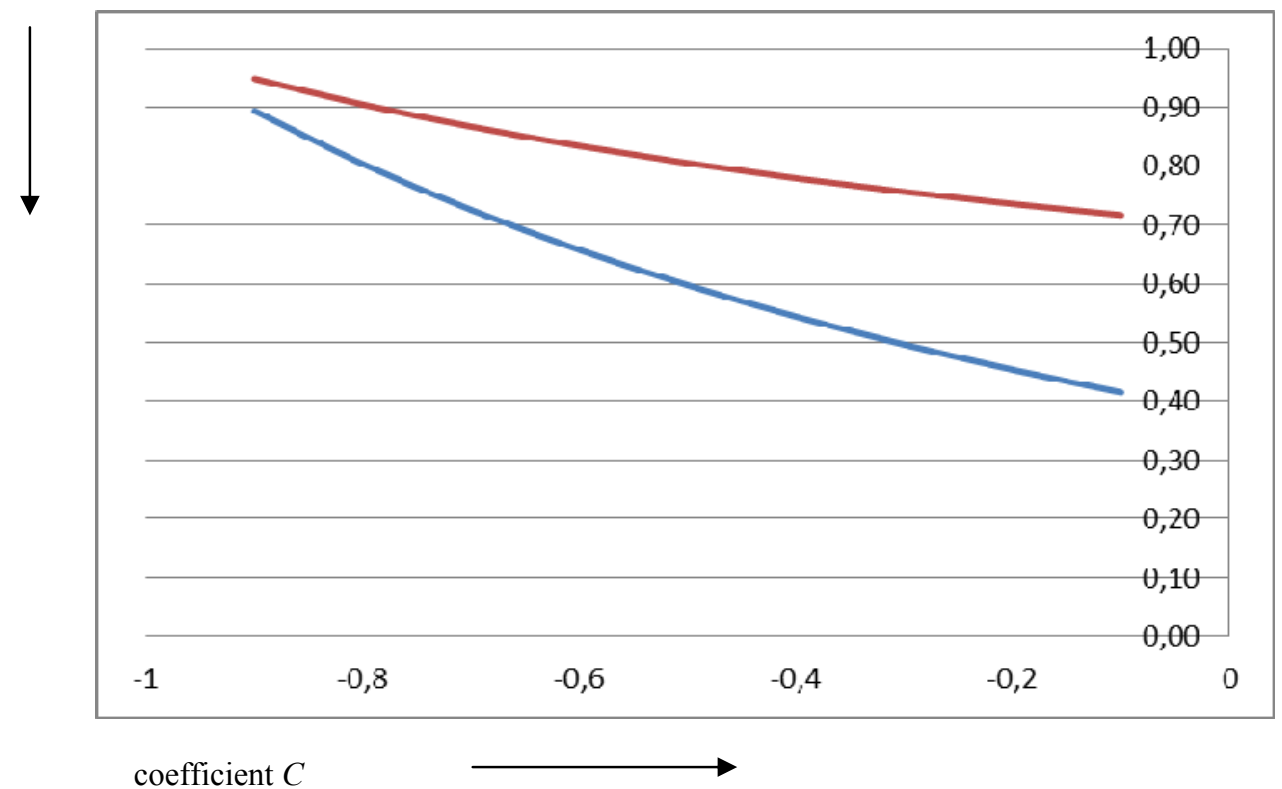

Note: The lower line represents the total impact on output growth of a 1\%-point increase in real wage growth when we assume that coefficient $\beta_{2}=0.38$; the upper line (in red) gives the total impact on output growth of a 1per cent-point increase in real wage growth when $\beta_{2}=0.70$.

But it must be noted that the employment creation is due more to the slowdown of (endogenous) productivity growth (by 0.31 percentage points) than to the expansion of output growth (by 0.16 percentage points). Clearly, real wage restraint also hampers productivity growth and technological dynamism in profit-led economies. Figure 5 shows that the more profit-led the economy is (the more strongly negative is $C$ ), the more effective is real wage restraint as an instrument to raise employment growth. But it can also be seen that if coefficient $C$ is small (say $C=0.10$ ) and coefficient $\beta_{2}$ is large (say, 0.70 ), then employment rises (and unemployment declines) in response to a real wage growth decline, mostly because of declining productivity growth while output growth is hardly affected.

\section{Evidence on OECD Employment Growth}

The message is sobering, perhaps: under realistic assumptions, higher real wage growth does not generate higher employment growth in a wage-led economy. We believe this is a fair conclusion, reflecting the stylized fact that the employment elasticity of growth in the OECD countries has increased in recent times, while real wage growth slowed down - as is illustrated in Figure 6.

Let us consider the historical facts for eleven major OECD economies, appearing in Table 3, more closely. It can be seen that average annual employment growth (measured 
in hours worked) in these countries during the 1990s was low; the un-weighted group average is an employment growth rate of 0.3 per cent per year. Hourly employment growth was negative in this period in Finland, Germany, Sweden, and the UK, and about zero in Belgium, France and Italy. It is only in Denmark, the Netherlands (as per our introduction), Spain and the U.S.A. that employment growth is higher. Average annual real GDP growth during 1990-1999 was 2.2 per cent and average labour productivity growth stood at about 2 per cent per annum. In the second period (2000-08), hourly employment growth increased in almost all countries which featured negative or zero employment growth in the 1990s: in Finland, the employment growth rate increased by a full 2 percentage points, in Belgium and Spain by more than 1 percentage point, and in France, Italy, Sweden and the UK by more than 0.55 percentage points. Employment growth also increased in Denmark and Germany (where it became less strongly negative) and only in the Netherlands and in the U.S., hourly employment growth rates fell after 2000. On average for the eleven countries, employment increased by 0.8 per cent per year during 2000-08.

The rise in employment growth cannot be attributed to an overall improvement in economic performance. To the contrary, average (un-weighted) real GDP growth declined from more than 2.2 per cent per year during the 1990s to less than 2 per cent during 2000-08. This means that the employment elasticity of GDP - defined as the ratio of hourly employment growth to real GDP growth - has increased, as it did, from less than 0.1 in the 1990s to more than 0.4 in the period 2000-08. OECD growth has, in other words, become more employment-intensive. We note that this is not true for the U.S., where the employment elasticity of growth declined from a value of 0.44 before 2000 to a value of 0.24 after 2000; this makes it understandable why there is so much discussion in the U.S. about jobless growth and jobless recovery from the crisis. But for Europe, with the exception of the Netherlands, the post-2000 years were a period of job growth.

The rise in employment growth (by 0.5 percentage points) and the drop in GDP growth (by about 0.3 percentage points) imply that labour productivity must have declined even more than real GDP growth. Labour productivity growth fell from an unweighted average of 2 per cent in the 1990s to only 1.2 per cent during 2000-08. Employment growth was thus achieved at the cost of productivity growth, closely mimicking the Dutch employment miracle of the 1990s. As we argued in the introduction, the Dutch jobs wonder was based on real wage restraint. What about the European employment growth revival post-2000? As can be seen from Table 3, real wage growth was lowered in most countries-most spectacularly in Germany, Belgium, Spain, Denmark and France. Figure 6 presents a scatter plot of real wage growth and employment elasticities (of GDP) for the eleven countries in the two periods 1990-99 and 2000-08; the data show, as per the fitted linear curve, that the employment elasticity elasticity of GDP increases, when real wage growth is lowered.

In our book Macroeconomics Beyond the NAIRU (Storm and Naastepad 2012) we have analyzed these eleven economies and found that most of them are wage-led economies (the U.S. is the single exception). A reduction in real wage growth will therefore lower real GDP growth - as we do observe in the data of Table 3 for most European economies (except Italy and Sweden). This finding matches with the observed increase in employment growth only if there is a considerable (induced) decline in productivity growth, brought about directly and indirectly (via the Kaldor-Verdoorn effect) by real wage moderation. Real wage growth, in other words, has a stronger impact on employment growth (and this effect operates through a slowdown of labour productivity growth) than on output growth - which is in line with our stylized findings. The Dutch employment miracle has definitely gone European. 
Figure 6 The employment elasticity of GDP declines when real wage growth rises.

Evidence for 11 OECD economies (1990-2008)

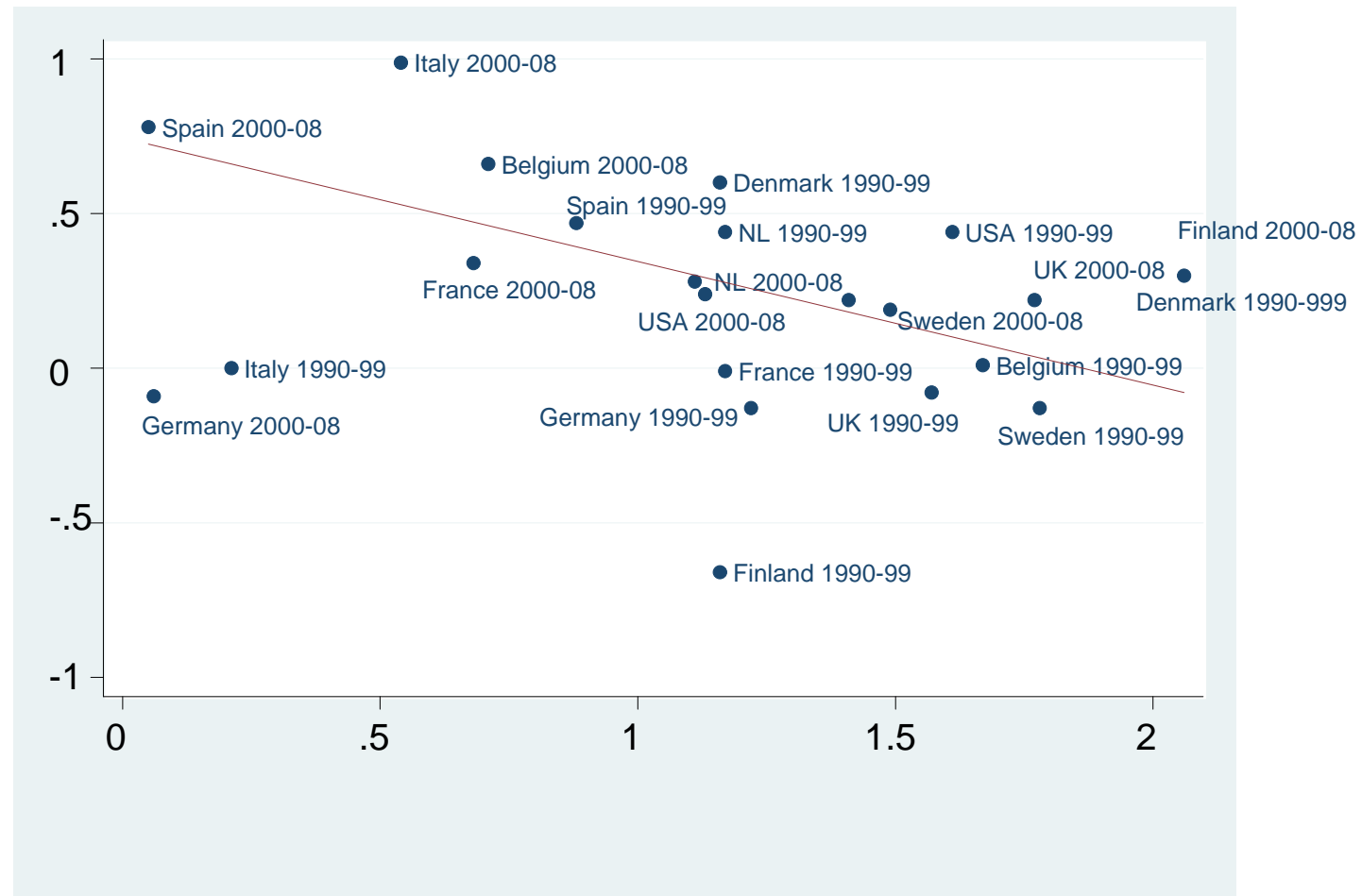

Notes: The fitted curve is based on the following OLS regression (with robust $t$-statistics):

Employment elasticity of GDP $=0.75-{ }^{*} 0.40$ real wage growth

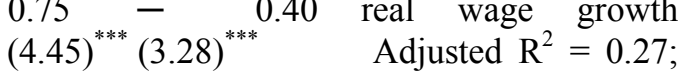

$\mathrm{F}=10.75 ; \mathrm{n}=20$

Italy (1990-99) and Germany (2000-08) are excluded from the regression. $* * *=$ statistically significant at 1 per cent. Employment is measured in total hours worked; GDP is in constant prices. Employment and GDP data are from the Groningen Growth and Development Centre's total economy database. The employment elasticity of GDP is defined as the ratio of average annual (hourly) employment to average annual real GDP growth. Data on real compensation per employee (GDP deflator, total economy) are from the AMECO Database. NL = the Netherlands.

\section{Wages, Productivity and Profits}

It follows that a major obstacle to egalitarian growth in a wage-led economy is an inherent one: the spectre of technological unemployment. Even in the most strongly wage-led countries in the OECD, wage-led is unlikely to be job-creating, as is illustrated in Figures 3 and 6. The reason is that wage-led growth is associated with labour-saving technological progress and high rates of labour productivity growth. One remedy to this problem is an overall reduction of individual working hours (as was done in Scandinavia); ignoring possible organisational complications, no valid objections can be raised so long as wages are reduced in proportion to the reduction in working hours and the growth of labour productivity. Specifically, by sharing available employment (hours), lack of, or even negative, employment growth does not lead to increased unemployment. 
We believe that successful co-ordinated employment sharing is possible only in a (strongly) wage-led economic system that responds to higher wage growth by expanding output and raising labour productivity; it would not be feasible when the economy contracts in reaction to higher real wage growth.

Why is such employment sharing acceptable to private sector firms? The answer is that, as firms and workers are operating under a fairness constraint, firms obtain more worker commitment, higher labour productivity as well as more demand, and greater worker willingness to co-operate in engendering (labour-saving) technological progress in exchange for the higher wage and a more egalitarian outcome. Crucially, the more rapid demand growth and even higher labour productivity growth enables firms to maintain their profitability (in real terms). To see this, let us define profit income $\Pi$ (in real terms) as the product of the profit share $\pi$ and output (i.e. $\Pi=\pi x$ ). It follows that profit income growth is equal to:

$$
\hat{\Pi}=\hat{\pi}+\hat{x}=-[\hat{w}-\hat{\lambda}]+\hat{x}
$$

The impact of an increase in real wage growth on profit income growth then is:

$$
\frac{\partial \hat{\Pi}}{\partial \hat{w}}=-1+\frac{\partial \hat{\lambda}}{\partial \hat{w}}+\frac{\partial \hat{x}}{\partial \hat{w}}
$$

Let us here consider the case of strongly wage-led economy. If the wage-led coefficient $\mathrm{C}$ takes a value of 0.85 (which is realistic for Europe's Nordic economies, see Storm and Naastepad 2012), and assuming as we did before that $\beta_{1}=0.46$ and $\beta_{2}=0.38$, we get:

$$
\frac{d \hat{x}}{d \hat{w}}=\frac{(1-0.38) C}{1+0.46 C}=\frac{0.62 \times 0.85}{1+0.46 \times 0.85}=+0.38
$$

This represents the total impact of a one-percentage point increase in real wage growth on output growth. Likewise, we obtain a numerical estimate of the effect of a onepercentage point increase in real wage growth on labour productivity growth as follows:

$$
\frac{d \hat{\lambda}}{d \hat{w}}=\beta_{2}+\beta_{1} \frac{d \hat{x}}{d \hat{w}}=0.38+0.46 \frac{d \hat{x}}{d \hat{w}}=0.38+0.46 \times 0.38=0.55
$$

If we substitute our numerical estimates of (13) and (14) into equation (12), we get:

$$
\frac{\partial \hat{\Pi}}{\partial \hat{w}}=-1+0.55+0.38=-0.07
$$

The finding is crucial: based on parameter values for a strongly wage-led economy (such as the Scandinavian ones), we find that the impact of a one percentage point increase in real wage growth on profit income growth is very small. Elsewhere we argue in more detail that the relative insensitivity of profitability to higher real wages, which is in large measure due to the relatively strong responsiveness of productivity growth to wage growth, provides the foundation for co-operative versions of capitalism such as the Nordic one (Storm and Naastepad 2012).

This Nordic model should be contrasted to the European Continental (EC), model. We take the Dutch case, closely examined by Naastepad (2006), which arguably is in 
many ways representative of other EC countries. Using Naastepad's estimates, we calculate the impact of a one percentage point increase in real wage growth on Dutch profit income growth as follows:

$$
\frac{\partial \hat{\Pi}}{\partial \hat{w}}=-1+0.34+0.04=-0.62
$$

Clearly, granting workers higher real wages is not an option for Dutch firms as their profitability will suffer. This sharp trade-off between real wage growth and profit growth helps to explain why Dutch unions did not push for higher pay but instead decided to bargain for more jobs by means of a social compromise, entailing a long-term (voluntary) commitment to real wage growth restraint (as we explained in the introduction). Predictably, this real wage restraint did lead to the recovery of firm profitability as well as to the so-called "Dutch employment miracle", which has been the by-product of a wagemoderation-induced productivity growth slowdown and technological regression. The contrast with the technologically more dynamic Nordic model being obvious, we may call the Nordic model "social-productivist", while labelling the Dutch model "socialstagnationist". The label "social-stagnationist" applies to most other EC economies, including France, Germany, Italy and Spain as well. This is apparent from Figure 7 which shows that, all other coefficients being the same, a higher coefficient $C$ (meaning that the economy in question is more strongly wage-led) is associated with lower sensitivity of profit income growth to increases in real wage growth. Based on the econometric findings in Storm and Naastepad (2012), it can be seen that for Germany, $\frac{\partial \hat{\Pi}}{\partial \hat{w}}$ would be the same $(-0.62)$ as for the Netherlands, while for Italy the sensitivity of profit growth to real wage growth is -0.56 , and for France and Spain it would take a value of about -0.4 . These European continental countries feature similarly weakly wage-led aggregate demand as the Dutch one and have also opted for high employment growth (and low wage growth) rather than high productivity growth, high wage growth and employment sharing. Figure 7 also features the profit-led US economy (having $C<0$ ): with profit-led demand, a one percentage-point increase in real wage growth translates into a decline in profit income growth by one percentage point; nowhere in the OECD is the conflict between wage growth and profit growth more pronounced than in the USA. 
Figure 7 The more strongly wage-led the economy, the less sensitive is profit income growth to real wage growth

decline in profit income growth

due to a one-percentage point

increase in real wage growth

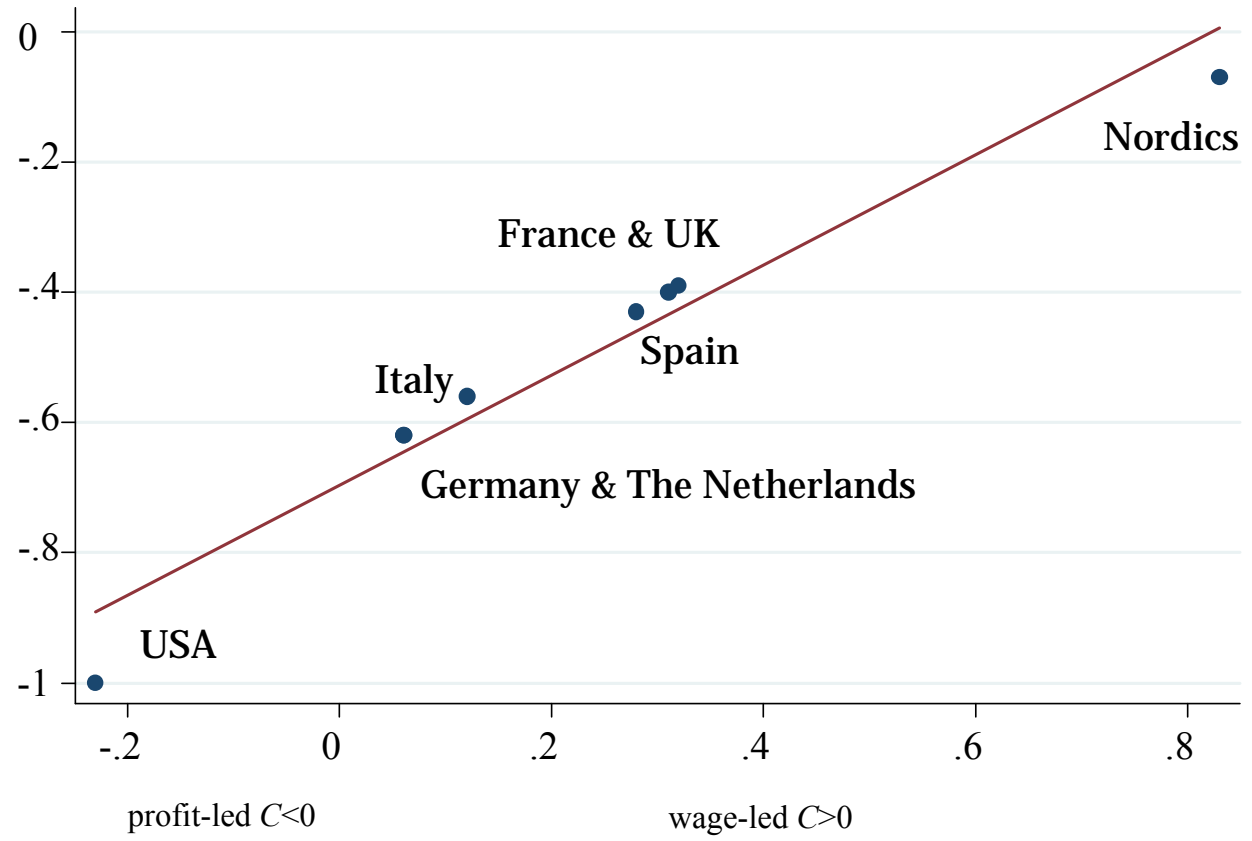

Note: The scatter points indicate the sensitivity of profit income growth to a change in real wage growth by 1 percentage point. The observed variation across countries in this sensitivity is only due to country-wise variations in the (wage-led/profit-led) coefficient $C$-all other coefficient values are identical to the Nordic coefficients $\beta_{1}=0.31, \beta_{2}=0.51$, and $\beta_{3}=0.54$.

Source: Storm and Naastepad (2012), Figure 7.3.

\section{Wages and Economic Recovery}

What can we say - based on the preceding discussion - about the role of wages in the economic recovery or, more broadly, in long-run growth? Perhaps we best start with a few negative policy lessons: what should not be done.

First, if the economy is wage-led, as is most of the European Union, real wage cuts and further deregulation of OECD labour markets will not create the conditions for a viable, sustained economic recovery but are a recipe for prolonged stagnation of output and productivity growth - especially now, with households, firms, and governments burdened by debts, there no longer exists an escape route through carefree borrowing as the one taken by the Dutch as well as the Americans before the crisis (Palma 2009; Palley 2009). However, real wage restraint may generate strong employment growth and lower unemployment, because it depresses labour productivity growth more than output growth - probably mostly creating low-wage, precarious "not-so-decent" services-sector jobs. What must be understood is that this strategy amounts to "working many more hours" in return for "less income" - neither an attractive nor a sensible proposition, and politically potentially self-destructive, especially since labour forces are about to become smaller because of demographic reasons (ageing). 
Second, if the economy is profit-led, as is the USA (Naastepad and Storm 2007), lowering real wage growth does raise output growth - but not very strongly so, because productivity growth drops off and technological progress gets bogged down. Profitability and investment will rise - but again not very strongly because lower productivity growth reduces the (expected) rate of return on investment. Employment growth will rise (and considerably so), but here also mostly in the form of low-productive, low-wage jobs. This is a scenario of "working more" in return for "a somewhat higher income" - which is neither an altogether agreeable prospect. Moreover, lowering real wages, by depressing investment demand and consumption, combined with the debt overhang, introduces a deflationary bias and creates a non-negligible risk of debt deflation in both wage-led and profit-led systems.

This much is clear, therefore: lowering wages will not get us on the road to economic recovery. But what about raising real wages: will this help? Surely, one could argue, higher real wages will stimulate output if the system is wage-led, and this in turn may create a virtuous cycle of higher investment, higher productivity and further growth-eventually also of employment. We beg to disagree. The "exogenoustechnology- Keynesian" view is too simple: yes, higher real wages raise output, but they increase labour productivity even more, and hence employment actually falls. Higher unemployment, combined with high debts in very uncertain times, means reluctant and wary consumers and investors and ultimately lacklustre demand growth. Higher real wages (per se) are no panacea - a cure for all economic diseases - not even in a wage-led economy. What is needed for recovery is a broader policy package to protect wages as well as profits, jobs as well as technological progress, and egalitarian outcomes as well as international non-price competitiveness (Storm and Naastepad 2012). Such a package should entail (1) a fair sharing of the gains of labour productivity growth and technological progress between business and labour; (2) an allowance for high enough profits to stimulate investment; and (3) a commitment to providing employment security both at the level of the firm and as a (full-employment) macroeconomic strategy. Real wages could (and should) be raised, but in combination with supportive macroeconomic policy, e.g. a low real interest rate and a system of taxation which progressively taxes the high-saving income groups to finance public-sector employment and R\&D. For profit-led economies, a similar approach will also pay off in terms of growth, productivity and employment. Higher real wages here depress output — but this can be compensated by appropriate output-enhancing interest rates and fiscal policy. The take-away of our analysis is a sobering asymmetry: lowering real wages will be unambiguously counterproductive, but the opposite policy of raising real wages will not have much of an impact on the economic recovery process. This may sound depressing.

But let our key message not be misunderstood: the argument that lower wages and further deregulation of (supposedly) rigid labour markets, all in the name of "increasing cost competitiveness", are the only possible way out of the recession, is dead wrongespecially for wage-led Europe - even though, as we made clear, the advocates of real wage restraint can claim that it may generate "jobs, jobs, jobs" (but very low-wage jobs and the aggregate economy remains otherwise stagnant). Neither the social democrats nor the labour unions in Europe have grasped this point - and in the past this has led them to accept real wage restraint and labour market deregulation in exchange for lower unemployment, as has happened in the Netherlands (and later on Germany). They should no longer accept this, and strongly demand both fair real wage increases and a credible commitment in macroeconomic policymaking to full employment (rather than low inflation) - demands which do not need to conflict with productivity growth and profitability (if properly managed). However, if these demands are to effectuate, they should be accompanied by the imposition of strict compulsions on capital-forcing shareholders to become more committed long-term investors (Lazonick 2009; Palma 2009; Wade 2009; Storm and Naastepad 2012). 


\section{References}

Alexiadis, Stilianos and Dimitrios Tsagdis. 2009. Is cumulative growth in manufacturing productivity slowing down in the EU12 regions? Cambridge Journal of Economics, advance on-line access.

Angeriz, Alvaro, John S.L. McCombie and Mark Roberts. 2009. Increasing returns and the growth of industries in the EU regions: paradoxes and conundrums. Spatial Economic Analysis 4 (2): 127-148.

Auer, Peter. 2000. Employment revival in Europe. Labour market successes in Austria, Denmark, Ireland and the Netherlands. Geneva: ILO.

Barbosa-Filho, Nelson H. and Lance Taylor. 2006. Distributive and demand cycles in the US economy - a structuralist Goodwin model. Metroeconomica 57 (3): 389-411.

Becker, Uwe and Herman Schwartz (eds). 2005. Employment miracles. Amsterdam: Amsterdam University Press.

Blanchard, Oliver. 2000. The Dutch jobs miracle. Available at: http://www.projectsyndicate.org/commentary/bla5/English

Bowles, Samuel and Robert Boyer. 1995. Wages, aggregate demand, and employment in an open economy: an empirical investigation. In Gerald Epstein and Herbert E. Gintis, eds., Macroeconomic policy after the conservative era - studies in investment, saving and finance, 143-171. Cambridge: Cambridge University Press.

Carlin, Wendy, Andrew Glyn, and John van Reenen. 2001. Export market performance of OECD countries: an empirical examination of the role of cost competitiveness. The Economic Journal, 111 (468): 128-162.

Carter, Scott. 2007. Real wage productivity elasticity across advanced economies, 1963-1999. Journal of Post Keynesian Economics 29 (4): 573-600.

Cornwall, John and Wendy Cornwall. 2002. A demand and supply analysis of productivity growth. Structural Change and Economic Dynamics 13 2): 203-229.

Crespi, Francesco and Mario Pianta. 2008. Demand and innovation in productivity growth. International Review of Applied Economics 22 (6): 655-672.

Economist, The. 2002. Model makers. A survey of the Netherland, May $2^{\text {nd }}$.

Foley, Duncan K. and Thomas R. Michl. 1999. Growth and distribution. Cambridge, MA: Harvard University Press.

Forslund, Anders, Nils Gottfries and Andreas Westermark. 2008. Prices, productivity and wage bargaining in open economies. Scandinavian Journal of Economics 110 (1): 169-195.

Funk, Peter. 2002. Induced innovation revisted. Economica 69 (273): 155-171.

Hein, Eckhard and Artur Tarassow. 2010. Distribution, aggregate demand and productivity growththeory and empirical results for six OECD countries based on a post-Kaleckian model. Cambridge Journal of Economics 34 (4): 727-754. 
Hicks, John R. 1932. The theory of wages. London: Macmillan.

Judt, Tony. 2010. Ill fares the land. A treatise on our present discontents. London: Penguin Books.

Kennedy, Charles. 1964. Induced bias in innovation and the theory of distribution. The Economic Journal 74: 541-547.

Knell, Mark. 2004. Structural change and the Kaldor-Verdoorn law in the 1990s. Revue d'économie industrielle 105 (1): 71-83.

Lavoie, Marc. 1992. Foundations of Post-Keynesian Analysis. Aldershot: Edward Elgar.

Lavoie, Marc and Engelbert Stockhammer. 2012. Wage-led growth: concept, theories and policies. Project Report for the Project "New Perspectives on Wages and Economic Growth: The Potentials of Wage-Led Growth", International Labour Office, Geneva.

Lazonick, William. 2009. The New Economy Business Model and the crisis of US capitalism. Capitalism and Society 4 (2). On-line article 4.

Leon-Ledesma, Miguel. 2002. Accumulation, innovation and catching-up: an extended cumulative growth model. Cambridge Journal of Economics 25 (2): 201-216.

Lowe, Adolph. 1988. Has freedom a future? New York: Praeger Publishers.

Marquetti, Adalmir A. 2004. Do rising real wages increase the rate of labor-saving technical change? Some econometric evidence. Metroeconomica 55(4): 432-441.

McCombie, John S.L., Maurizio Pugno and Bruno Soro, eds. 2002. Productivity growth and economic performance: Essays on Verdoorn's Law. London: Macmillan.

Naastepad, C.W.M. 2006. Technology, demand and distribution: a cumulative growth model with an application to the Dutch productivity growth slowdown. Cambridge Journal of Economics 30 (3): 403-434.

Naastepad, C.W.M. and Servaas Storm. 2007. OECD demand regimes (1960-2000). Journal of Post Keynesian Economics 29 (2): 211-246.

Nikiforos, Michalis and Duncan K. Foley. 2012. Distribution and capacity utilisation: conceptual issues and empirical evidence. Metroeconomica 63 (1): 200-229.

Nymoen, Ragnar and Asbjørn Rødseth. 2003. Explaining unemployment: some lessons from Nordic wage formation. Labour Economics, 10 (1): 1-29.

Onaran, Özlem and Giorgos Galanis. 2012. Is aggregate demand wage-led or profit-led? National and global effects. Project Report for the Project "New Perspectives on Wages and Economic Growth: The Potentials of Wage-Led Growth", International Labour Office, Geneva.

Onaran, Özlem, Engelbert Stockhammer and Lukas Grafl. 2011. The finance-dominated growth regime, distribution and aggregate demand in the US. Cambridge Journal of Economics, 35 (4): 637-661.

Palma, José Gabriel. 2009. The revenge of the market on the rentiers. Why neo-liberal reports of the end of history turned out to be premature. Cambridge Journal of Economics 33 (4): 829-869. 
Palley, Thomas. 2009. America's exhausted paradigm: macroeconomic causes of the financial crisis and the great recession. New American Contract Policy Paper. Washington, DC: New America Foundation.

Rowthorn, Robert E. 1999. Unemployment, wage bargaining and capital-labour substitution. Cambridge Journal of Economics 23(4): 413-425.

Salverda, Wiemer. 2009. The Dutch minimum wage. A radical reduction shifts the main focus to parttime jobs. Working paper 09-71. Amsterdam Institute for Advanced Labour Studies, University of Amsterdam.

Stockhammer, Engelbert, Özlem Onaran and Stefan Ederer. 2009. Functional income distribution and aggregate demand in the Euro area. Cambridge Journal of Economics 33 (1): 139-159.

Storm, Servaas and C.W.M. Naastepad. 2011. The productivity and investment effects of wage-led growth. International Journal of Labour Research 3 (2): 197-218.

Storm, Servaas and C.W.M. Naastepad. 2012. Macroeconomics Beyond the NAIRU. Cambridge, MA: Harvard University Press.

Tavani, Daniele, Peter Flaschel and Lance Taylor. 2011. Estimated non-linearities and multiple equilibria in a model of distributive-demand cycles. International Review of Applied Economics 25 (5): 519-538.

Taylor, Lance. 2010. Maynard's revenge: Keynesianism and the collapse of free market macroeconomics. Cambridge, MA: Harvard University Press.

Vergeer, Robert and Alfred Kleinknecht. 2010-11. The impact of labor market deregulation on productivity: a panel data analysis of 19 OECD countries (1960-2004). Journal of Post Keynesian Economics 33 (2): 369-405.

Weitzman, Martin. 2007. A review of the Stern Review on the Economics of Climate Change. Journal of Economic Literature 45 (3): 703-724. 


\section{Conditions of Work and Employment Series}

No. 1 Quality of working life: A review on changes in work organization, conditions of employment and work-life arrangements (2003), by H. Gospel

No. 2 Sexual harassment at work: A review of preventive measures (2005), by D. McCann

No. 3 Statistics on working time arrangements based on time-use survey data (2003), by A. S. Harvey, J. Gershuny, K. Fisher \& A. Akbari

No. 4 The definition, classification and measurement of working time arrangements (2003), by D. Bell \& P. Elias

No. 5 Reconciling work and family: Issues and policies in Japan (2003), by M. Abe, C. Hamamoto \& S. Tanaka

No. 6 Reconciling work and family: Issues and policies in the Republic of Korea (2004), by T.H. Kim \& K.K. Kim

No. 7 Domestic work, conditions of work and employment: A legal perspective (2003), by J.M. Ramirez-Machado

No. 8 Reconciling work and family: Issues and policies in Brazil (2004), by B. Sorj

No. 9 Employment conditions in an ageing world: Meeting the working time challenge (2004), by A. Jolivet \& S. Lee

No. 10 Designing programmes to improve working and employment conditions in the informal economy: A literature review (2004), by Dr. R.D. Rinehart

No. 11 Working time in transition: The dual task of standardization and flexibilization in China (2005), by X. Zeng, L. Lu \& S.U. Idris

No. 12 Compressed working weeks (2006), by P. Tucker

No. 13 Étude sur les temps de travail et l'organisation du travail: Le cas du Sénégal. Analyse juridique et enquête auprès des entreprises (2006), by A. Ndiaye

No. 14 Reconciling work and family: Issues and policies in Thailand (2006), by K. Kusakabe

No. 15 Conditions of work and employment for older workers in industrialized countries: Understanding the issues (2006), by N.S. Ghosheh Jr., S. Lee \& D. McCann

No. 16 Wage fixing in the informal economy: Evidence from Brazil, India, Indonesia and South Africa (2006) by C. Saget

No. 18 Reconciling work and family: Issues and policies in Trinidad and Tobago (2008), by R. Reddock \& Y. Bobb-Smith 
No. 19 Minding the gaps: Non-regular employment and labour market segmentation in the Republic of Korea (2007) by B.H. Lee \& S. Lee

No. 20 Age discrimination and older workers: Theory and legislation in comparative context (2008), by N. Ghosheh

No. 21 Labour market regulation: Motives, measures, effects (2009), by G. Bertola

No. 22 Reconciling work and family: Issues and policies in China (2009), by Liu Bohong, Zhang Yongying \& Li Yani

No. 23 Domestic work and domestic workers in Ghana: An overview of the legal regime and practice (2009), by D. Tsikata

No. 24 A comparison of public and private sector earnings in Jordan (2010), by C. Dougherty

No. 25 The German work-sharing scheme: An instrument for the crisis (2010), by A. Crimmann, F. Weissner, L. Bellmann

No. 26 Extending the coverage of minimum wages in India: Simulations from household data (2010), by P. Belser \& U. Rani

No. 27 The legal regulation of working time in domestic work (2010), by Deirdre Mc Cann \& Jill Murray

No. 28 What do we know about low-wage work and low-wage workers (2011), by Damian Grimshaw

No. 29 Estimating a living wage: a methodological review (2011), by Richard Anker

No. 30 Measuring the economic and social value of domestic work: conceptual and methodological framework (2011), by Debbie Budlender

No. 31 Working Time, Health, and Safety: a Research Synthesis Paper (2012), prepared by Philip Tucker and Simon Folkard, on behalf of Simon Folkard Associates Ltd

No. 32 The influence of working time arrangements on work-life integration or 'balance': A review of the international evidence (2012), by Colette Fagan, Clare Lyonette, Mark Smith and Abril Saldaña-Tejeda

No. 33 The Effects of Working Time on Productivity and Firm Performance: a research synthesis paper (2012), by Lonnie Golden

No. 34 Estudio sobre trabajo doméstico en Uruguay (2012), by Dra. Karina Batthyány

No. 35 Why have wage shares fallen? A panel analysis of the determinants of functional income distribution (2012), by Engelbert Stockhammer

No. 36 Wage-led or Profit-led Supply: Wages, Productivity and Investment (2012), by Servaas Storm \& C.W.M. Naastepad

No. 37 Financialisation and the requirements and potentials for wage-led recovery - a review focussing on the G20 (2012), by Eckhard Hein and Matthias Mundt

No 38 Wage Protection Legislation in Africa (2012), by Najati Ghosheh 
No. 39 Income inequality as a cause of the Great Recession? A survey of current debates (2012), by Simon Sturn \& Till van Treeck

No. 40 Is aggregate demand wage-led or profit-led? National and global effects (2012), by Özlem Onaran \& Giorgos Galanis

No. 41 Wage-led growth: Concept, theories and policies (2012), by Marc Lavoie \& Engelbert Stockhammer 
Table 1 Estimates of the impact of (investment) demand growth on productivity growth

\begin{tabular}{|c|c|c|c|c|c|c|c|}
\hline & France & Germany & Netherlands & $U K$ & $U S A$ & The Nordic countries & OECD countries \\
\hline McCombie et al. (2002) & & & & & & & $0.3-0.6$ \\
\hline $\begin{array}{l}\text { Cornwall and Cornwall } \\
\text { (2002) }\end{array}$ & & & & & & & 0.5 \\
\hline Leon-Ledesma (2002) & & & & & & & $0.64-0.67$ \\
\hline Knell (2004) & 0.43 & & & 0.53 & 0.43 & $0.40-0.76$ & \\
\hline Naastepad (2006) & & & 0.63 & & & & \\
\hline Angeriz et al. (2008) & & & & & & & $0.50-0.67$ \\
\hline Crespi and Pianta (2008) & & & & & & & $0.27-0.38$ \\
\hline Hein and Tarassow (2009) & 0.54 & 0.43 & 0.45 & 0.23 & 0.11 & & \\
\hline Storm and Naastepad (2011) & & & & & & 0.31 & $0.39-0.46$ \\
\hline Alexiadis and Tsagdis (2010) & & & & & & & $0.43-0.49$ \\
\hline $\begin{array}{l}\text { Vergeer and Kleinknecht } \\
(2010-11)\end{array}$ & & & & & & & $0.24-0.37$ \\
\hline $\begin{array}{l}\text { simple average (standard } \\
\text { deviation) }\end{array}$ & $0.49(0.08)$ & 0.43 & $0.54(0.13)$ & $0.38(0.21)$ & $0.27(0.23)$ & $0.45(0.19)$ & $0.46(0.12)$ \\
\hline
\end{tabular}

Notes: McCombie et al. (2002): average of 80 empirical studies; Cornwall and Cornwall (2002): based on data for 16 OECD countries (1960-1989); Leon-Ledesma (2002): for 18 OECD countries (1965-1994); Angeriz, McCombie and Roberts (2008): for European regions (1986-2002); Crespi \& Pianta (2008): data cover 22 manufacturing and 10 service industries in France, Germany, Italy, the Netherlands , Portugal and the UK (1994-2000); Alexiadis and Tsagdis (2010): based on data (1977-2005) for 109 EU12 regions; Storm and Naastepad (2009): OLS estimates using 5-year average data for 20 OECD countries (1984-2004);

and Vergeer and Kleinknecht (2010-11): panel data results based on annual data for 19 OECD countries (1960-2004). 
Table 2 Estimates of the impact of real wage growth on productivity growth

\begin{tabular}{|c|c|c|c|c|c|c|c|}
\hline & France & Germany & Netherlands & $U K$ & $U S A$ & The Nordic countries & OECD countries \\
\hline Rowthorn (1999) & $0.11-0.24$ & $0.33-0.87$ & $0.24-0.44$ & $0.25-0.60$ & $0.13-0.28$ & $0.10-0.54$ & $0.24-0.30$ \\
\hline Nymoen and Rødseth (2003) & & & & & & 0.50 & \\
\hline Naastepad (2006) & & & 0.52 & & & & \\
\hline Carter (2007) & & & & & & & 0.60 \\
\hline Hein and Tarassow (2009) & 0.31 & 0.32 & 0.33 & 0.25 & 0.36 & & \\
\hline Storm and Naastepad (2009/2011) & & & & & & & 0.29 \\
\hline Vergeer and Kleinknecht (2010-11) & & & & & & & $0.31-0.39$ \\
\hline simple average (standard deviation) & $0.24(0.10)$ & $0.46(0.20)$ & $0.43(0.13)$ & $0.34(0.12)$ & $0.28(0.11)$ & $0.41(0.13)$ & $0.38(0.15)$ \\
\hline
\end{tabular}

Notes: Rowthorn (1999): data are from his Table 2, panel (b); Nymoen and Rødseth (2003): for the four Nordic countries (1965-1994); Carter (2007): based on data for 15 OECD countries (1980-1996); Storm and Naastepad (2009): OLS estimates using 5-year average data for 20 OECD countries (1984-2004); and Vergeer and Kleinknecht (2010-11): panel data results based on annual data for 19 OECD countries (19602004). 
Table 3 Real GDP growth, hourly employment growth, labour productivity growth and real wage growth:

Eleven OECD countries 1990-1999 and 2000-08

\begin{tabular}{|c|c|c|c|c|c|c|c|c|}
\hline & \multicolumn{4}{|c|}{ 1990-1999 } & \multicolumn{4}{|c|}{$2000-2008$} \\
\hline & $\begin{array}{c}\text { Real } \\
\text { GDP } \\
\text { growth }\end{array}$ & $\begin{array}{l}\text { employment } \\
\text { growth }\end{array}$ & $\begin{array}{l}\text { labour } \\
\text { productivity } \\
\text { growth }\end{array}$ & $\begin{array}{c}\text { real } \\
\text { wage } \\
\text { growth }\end{array}$ & $\begin{array}{c}\text { Real } \\
\text { GDP } \\
\text { growth }\end{array}$ & $\begin{array}{l}\text { employment } \\
\text { growth }\end{array}$ & $\begin{array}{l}\text { labour } \\
\text { productivity } \\
\text { growth }\end{array}$ & $\begin{array}{c}\text { real } \\
\text { wage } \\
\text { growth }\end{array}$ \\
\hline Belgium & 2.06 & 0.03 & 2.03 & 1.67 & 1.81 & 1.20 & 0.61 & 0.71 \\
\hline Denmark & 2.49 & 0.55 & 1.94 & 1.77 & 1.26 & 0.75 & 0.51 & 1.16 \\
\hline Finland & 1.70 & -1.12 & 2.82 & 1.16 & 2.98 & 0.88 & 2.10 & 2.06 \\
\hline France & 1.78 & -0.01 & 1.79 & 1.17 & 1.58 & 0.54 & 1.04 & 0.68 \\
\hline Germany & 1.81 & -0.23 & 2.04 & 1.22 & 1.37 & -0.12 & 1.49 & 0.06 \\
\hline Italy & 1.35 & 0.00 & 1.35 & 0.21 & 0.82 & 0.81 & 0.01 & 0.54 \\
\hline Netherlands & 3.08 & 1.36 & 1.72 & 1.17 & 1.96 & 0.54 & 1.42 & 1.11 \\
\hline Spain & 2.79 & 1.32 & 1.47 & 0.88 & 3.09 & 2.42 & 0.67 & 0.05 \\
\hline Sweden & 1.83 & -0.23 & 2.06 & 1.78 & 2.55 & 0.55 & 2.00 & 1.41 \\
\hline UK & 2.38 & -0.18 & 2.56 & 1.57 & 2.23 & 0.42 & 1.81 & 1.49 \\
\hline USA & 3.33 & 1.48 & 1.85 & 1.61 & 2.02 & 0.48 & 1.54 & 1.13 \\
\hline
\end{tabular}

Sources: Employment is measured in total hours worked; GDP is in constant prices. Employment and GDP data are from the Groningen Growth and Development Centre's total economy database. Data on real compensation per employee (GDP deflator, total economy) are from the AMECO Database. 